Upaya Kepala Sekolah Dalam Meningkatkan Kinerja Guru Ekonomi

Melalui Supervisi Klinis di Sekolah Menengah Atas Negeri 3 Ponorogo

\title{
Upaya Kepala Sekolah Dalam Meningkatkan Kinerja Guru Ekonomi Melalui Supervisi Klinis di Sekolah Menengah Atas Negeri 3 Ponorogo
}

\author{
Sasmito Pribadi \\ Kepala Sekolah Menengah Atas Negeri 3 Ponorogo \\ e-mail: mitobadi@gmail.com
}

\begin{abstract}
Clinical supervision as peer professional assistance is given to teachers who experience problems in learning so that the teacher concerned can overcome the problem by taking systematic steps including the planning stage, the stage of observing the behavior of the teaching teacher, as well as the stage of behavior analysis and follow-up. The research design to be carried out is to use School Action Research (PTS). The method of collecting data is through observation, field notes and documentation. The data analysis techniques used are: (1) data reduction, (2) data presentation, (3) drawing conclusions. The results of the research are: the principal's efforts through clinical supervision are carried out on teachers, it can improve teacher performance as evidenced by increasing teacher performance from the beginning before the action by $58.2 \%$, after the first cycle of action it becomes $70.1 \%$, and after the second cycle of action it increases again to $83.7 \%$. The results of research on clinical supervision of high-grade teachers have been shown to provide an increase in teacher performance which in turn has an impact on improving student learning outcomes.
\end{abstract}

Keywords: headmaster, teacher performance, clinical supervision

\section{Pendahuluan}

Guru merupakan komponen pendidikan yang sangat dominan dalam meningkatkan mutu pendidikan. Hal ini disebabkan oleh karena guru adalah orang yang terlibat langsung dalam proses pembelajaran di sekolah. Agar proses pelajaran berkualitas maka guru-gurunya juga harus berkualitas dan professional. Di samping itu, guru sangat erat kaitannya dengan mutu lulusan sekolah. Kadar kualitas guru ternyata dipandang sebagai penyebab kadar kualitas out-put sekolah. Oleh karena itu, profesi sumber daya guru perlu terus menerus tumbuh dan berkembang agar dapat melakukan fungsinya secara professional. Salah satu cara untuk menumbuh kembangkan kemampuan sumber daya guru adalah supervisi.

Salah seorang yang diberi tanggung jawab untuk melakukan supervisi adalah kepala sekolah, sehingga kepala sekolah disebut juga sebagai supervisor. Sebagai supevisor kepala sekolah memberi bantuan dan bimbingan secara profesional kepada guru yang kurang memiliki kemampuan professional dalam mengajar. Supervisi perlu sekali dilakukan sebagai alat untuk mengetahui proporsi kualitas guru dalam menjalankan kegiatan belajar mengajar. Aspek yang diberikan dalam supervisi yang ada biasanya hanya 
bersifat umum, karena guru tidak dilibatkan dalam perencanaan pembuatan supervisi padahal nantiya guru mendapatkan follow up dari supervisi yang sudah dilakukan.

Kepala sekolah sebagai pemegang tampuk tertinggi di sekolah harus memahami keperluan pendidikan terutama untuk pelaksanaan supervisi. Segala kebutuhan guru yang meliputi pengajaran dan kurikulum menjadi pusat perhatian kepala sekolah untuk mendapatkan hasil kegiatan belajar mengajar (KBM) yang maksimal, oleh karena itu kepala sekolah perlu memahami dasar supervisi, baik supervisi klinis ataupun supervisi pendidikan.

Supervisi secara garis besar bertujuan untuk membantu guru meningkatkan kualitas pengajaran, hal ini biasanya masih kurang dipahami kepala sekolah dimana supervisi yang dilakukan malah sifatnya mencari kesalahan guru secara mendasar. Oleh karenanya, kepala sekolah perlu mencermati dasar atas supervisi yang sudah direncanakan, bukan hanya formalitas kebutuhan substansi pendidikan tapi sebagai tujuan utama dalam pelaksanaan kualitas sekolah. Dalam jabatan sebagai kepala sekolah, perlu sekali memahami dengan benar dasar yang dibutuhkan guru untuk pelaksanaan supervisi.

Hal ini menyangkut metode supervisi yang digunakan yakni supervisi klinis. Supervisi klinis merupakan salah satu jenis supervisi yang dilakukan oleh kepala sekolah terhadap guru. Jenis supervisi ini merupakan bantuan professional yang diberikan secara sistematik kepada guru berdasarkan kebutuhan guru tersebut dengan tujuan untuk membina guru serta meningkatkan profesionalisme guru dalam melaksanakan proses belajar mengajar.

Banyak guru yang mengalami kesulitan atau masalah dalam melaksanakan pembelajaran pada mata pelajaran yang diampunya. Kesulitan tersebut dapat disebabkan oleh karakteristik mata pelajaran sehingga sulit dipahami guru atau kesulitan dalam aspekaspek teknis metodologis sehingga bahan ajar kurang dipahami peserta didik. Supervisi yang dilakukan pengawas sekolah kepada guru merupakan salah satu upaya membantu guru untuk mengatasi masalah yang dialaminya dalam rangka memperbaiki kualitas pembelajaran.

Kepala sekolah selaku supervisor klinis selain sebagai penanggung jawab kepada tugas-tugas supervisi klinis, juga harus melakukan akuntabilitas terhadap tugas-tugas tersebut. Maksudnya jika tanggung jawab merupakan usaha agar apa yang dibebankan kepadanya dapat diselesaikan sebagaimana mestinya dalam waktu tertentu, maka akuntabilitas harus melebihi dari kewajiban itu. Akuntabilitas adalah kondisi seseorang 
yang dinilai oleh orang lain karena kualitas performannya menyelesaikan tujuan yang menjadi tanggung jawabnya. Dengan kata lain, keberhasilan supervisi klinis untuk mencapai profesionalisme guru sangat tergantung kepada sejauh mana tingkat akuntabilitasnya kepala sekolah. Untuk mencapai tingkat akuntabilitas yang tinggi dalam melaksanakan supervisi klinis kepala sekolah memerlukan pengetahuan dan ketrampilan tentang supervisi klinis itu sendiri.

Supervisi klinis ini diharap berperan aktif dalam meningkatkan kinerja guru, sebab meskipun guru sudah memperoleh pendidikan yang menjadi persyaratan pedagogisnya, guru juga tetap memerlukan adanya pendidikan untuk meningkatkan profesi (profesional growth) terutama bagi guru yang sudah bekerja (intenvice education). Salah satu cara untuk mewujudkan hal itu bisa dilakukan melalui supervisi klinis yang nantinya diharapkan akan dapat meningkatkan profesionalisme guru.

Banyak guru yang mengalami masalah atau kesulitan dalam melaksanakan pembelajaran pada mata pelajaran yang diampunya. Kesulitan tersebut dapat disebabkan oleh karakteristik mata pelajaran sehingga sulit dipahami guru atau kesulitan dalam aspekaspek teknis metodologi sehingga bahan ajar kurang dipahami peserta didik. Supervisi klinis yang dilakukan pengawas sekolah kepada guru merupakan salah satu upaya membantu guru untuk mengatasi masalah yang dialami dalam rangka memperbaiki kualitas pembelajaran.

Penelitian ini didukung dengan penelitian yang dilakukan oleh Lestaris (2019) dalam penelitiannya kepala sekolah dalam melakukan supervisi klinis mampu meningkatkan kinerja guru lebih baik dan kepala sekolah sebagai pelaksana dari supervisi klinis harus paham dan memiliki strategi yang mampu memberikan perubahan bagi guru. Supervisi klinis sebagai bantuan professional kesejawatan yang diberikan kepada guru yang mengalami masalah dalam pembelajaran agar guru yang bersangkutan dapat mengatasi masalahnya dengan menempuh langkah yang sistematis mencakup tahapan perencanaan, tahapan pengamatan perilaku guru mengajar, serta tahap analisis perilaku dan tindak lanjut. Strategi yang dilakukan oleh kepala sekolah dalam meningkatkan kinerja guru yaitu pemantauan, pemeriksaan, penilaian dan perbaikan. Kinerja guru harus ditingkatkan dan diprioritaskan. Karena seorang guru yang dapat meningkatkan dan mengembangkan kualitas dan potensi peserta didik. Tujuan dalam penelitian ini adalah untuk mengetahui upaya kepala sekolah dalam meningkatkan kinerja guru ekonomi melalui supervisi klinis di SMAN 3 Ponorogo. 


\section{Tinjauan Pustaka}

\section{Supervisi Klinis}

Supervisi klinis pada mulanya, dirancang sebagai salah satu model atau pendekatan dalam melakukan supervisi pengajaran terhadap calon guru yang sedang berpraktik mengajar. Dalam supervisi ini penekanannya pada klinik yang diwujudkan dalam bentuk hubungan tatap muka antara supervisor dan calon guru yang sedang berpraktik (Maunah, 2009, p.75).

Dikatakan supervisi klinis karena prosedur pelaksanaannya lebih ditekankan kepada mencari sebab-sebab atau kelemahan yang terjadi di dalam proses belajar mengajar dan kemudian secara langsung pula diusahakan bagaimana cara memperbaiki kelemahan atau kekurangan tersebut (Purwanto, 2007, p.90).

Supervisi klinis adalah (partnership in inquiry) antara dua orang yang mengandung alternatif, dimana supervisor berposisi sebagai patner yang lebih berpengalaman dalam inquiri, yang dapat membantu supervisor dan guru menggali alternatif secara kooperatif. Adapun Sahertian mendefinisikan supervisi klinis sebagai berikut: Supervisi klinis adalah suatu proses pembimbingan dalam pendidikan yang bertujuan mambantu pengembangan profesional guru dalam pengenalan mengajar melalui observasi dan analisis data secara obyektif teliti sebagai dasar untuk mengubah perilaku mengajar guru (Sahertian, 2000, p.37).

Dari beberapa pengertian di atas maka dapat diambil kesimpulan bahwa supervisi klinis adalah suatu teknik supervisi yang dilakukan oleh supervisor untuk memberi bantuan yang bersifat profesional yang diberikan berdasarkan kebutuhan guru yang bersangkutan dalam mengatasi masalah yang dihadapi dalam proses belajar mengajar melalui bimbingan yang intensif yang disusun secara sistematis dengan tujuan untuk meningkatkan kemampuan mengajar dan meningkatkan profesionalisme guru. Bimbingan yang diberikan tidak bersifat inspeksi atau perintah tetapi diberikan dengan cara sedemikian rupa sehingga memotifasi guru untuk menemukan sendiri cara-cara yang tepat dalam memperbaiki kekurangan yang dialami dalam proses pembelajaran.

Supervisi kinis pada dasarnya merupakan pembinaan performan guru dalam mengelola proses belajar mengajar. Pelaksanaannya didesain dengan praktis serta rasional. Baik desainnya maupun pelaksanaannya dilakukan atas dasar analisis data mengenai keiatan-kegiatan di kelas. Sasaran utama yang harus menjadi perhatian Supervisor baik 
pada saat guru mempersiapkan diri sebelum mengajar pada saat mengajar, dan setelah mengajar adalah: a) Kesadaran dan kepercayaan guru akan dirinya sebagai tenaga professional, dan; b) Keterampilan-keterampilan dasar mengajar yang diperlukan (Soetopo, 2006).

\section{Kinerja Guru}

Secara etimologi menurut Rue dan Byars dalam Amin (2007, p.7), menegaskan bahwa kinerja adalah tingkat pencapaian hasil atau degree of accomplishment atau dengan kata lain kinerja merupakan tingkat pencapaian tujuan. Istilah kinerja guru berasal dari kata job performancelactual permance (prestasi kerja atau prestasi sesungguhnya yang dicapai oleh seseorang). Sedangkan secara bahasa kinerja bisa diartikan sebagai prestasi yang nampak sebagai bentuk keberhasilan kerja pada diri seseorang. Keberhasilan kinerja juga ditentukan dengan pekerjaan serta kemampuan seseorang pada bidang tersebut. Keberhasilan kerja juga berkaitan dengan kepuasan kerja seseorang (Mangkunegara, 2000, p.67).

Sedangkan secara terminology Prawirosentono (1999, p.2) menegaskan bahwa kinerja merupakan terjemahan dari kata performance yang berarti hasil kerja yang dapat dicapai seseorang atau sekelompok orang dalam suatu organisasi, sesuai dengan wewenang dan tanggung jawab masing masing, dalam upaya mencapai tujuan secara legal, tidak melanggar hukum dan sesuai moral dan etika.

Prestasi bukan berarti banyaknya kejuaraan yang diperoleh guru tetapi suatu keberhasilan yang salah satunya nampak dari suatu proses belajar-mengajar. Untuk mencapai kinerja maksimal, guru harus berusaha mengembangkan seluruh kompetensi yang dimilikinya dan juga manfaatkan serta ciptakan situasi yang ada dilingkungan sekolah sesuai dengan aturan yang berlaku. Kinerja (prestasi kerja) merupakan hasil kerja secara kualitas dan kuantitas yang dicapai oleh seorang pegawai dalam melaksanakan tugasnya sesuai dengan tanggung jawab yang diberikan.

Dalam kamus bahasa Indonesia (2008, p.576). Kinerja berarti sesuatu yang dicapai, prestasi diperlihatkan, kemampuan kerja. Seseorang untuk melaksanakan tugasnya yang baik untuk menghasilkan hasil yang memuaskan, guna tercapainya tujuan sebuah organisasi atau kelompok dalam suatu unit kerja. Jadi, kinerja guru merupakan hasil kerja dimana para guru mencapai persyaratan-persyaratan pekerjaan (Simamora, 1995, p.433). 
Seorang mempunyai empat fungsi umum yang merupakan ciri pekerja seorang guru, adalah sebagai berikut:

1. Merencanakan

Yaitu pekerjaan seorang guru menyusun tujuan belajar.

2. Mengorganisasikan

Yaitu pekerjaan seorang guru untuk mengatur dan menghubungkan sumber-sumber belajar sehingga dapat mewujudkan tujuan belajar dengan cara yang paling efektif, efesien, dan ekonomis mungkin.

3. Memimpin

Yaitu pekerjaan seorang guru untuk memotivasikan, mendorong, dan menstimulasikan murid-muridnya, sehingga mereka siap mewujudkan tujuan belajar.

4. Mengawasi

Yaitu pekerjaan seorang guru untuk menentukan apakah fungsinya dalam mengorganisasikan dan memimpin diatas telah berhasil dalam mewujudkan tujuan yang telah dirumuskan. Jika tujuan belum dapat diwujudkan, maka guru harus menilai dan mengatur kembali situasinya dan bukunya mengubah tujuan (Devies, 1987, p.35).

Dengan demikian, menyimpulkan bahwa yang dimaksud kinerja guru adalah kemampuan seorang guru untuk melaksanakan tugasnya yang menghasilkan hasil yang memuaskan, guna tercapainya tujuan organisasi kelompok dalam suatu unit kerja. Jadi, kinerja guru dalam proses belajar mengajar adalah kemampuan guru dalam melaksanakan tugasnya sebagai pengajar yang memiliki keahlian mendidik anak didik dalam rangka pembinaan peserta didik untuk tercapainya tujuan institusi pendidikan.

Hipotesis tindakannya adalah: Jika upaya kepala sekolah melalui supervisi klinis dilakukan pada guru ekonomi, maka kinerja guru ekonomi dapat meningkat.

\section{Metode Penelitian}

Pendekatan yang digunakan dalam penelitian ini adalah pendekatan deskriptif kualitatif. Dimana dalam teknik menganalisis data kualitatif dilakukan dengan menelaah seluruh data, mereduksi data, menafsirkan data, dan memberikan pemaknaan hasil. Metode yang digunakan dalam penelitian ini adalah metode Penelitian Tindakan Sekolah (PTS). Artinya, penelitian ini dilakukan karena ditemukan permasalahan Permasalahan 
yang terjadi yaitu kurangnya kemampuan guru dalam penggunaan media pembelajaran kurangnya kesadaran guru dalam penggunaan media pembelajaran tidak optimalnya penggunaan media pembelajaran dari hasil identifikasi masalah yang muncul peneliti akan membatasi permasalahan yang disinyalir oleh peneliti sebagai akar permasalahan dari semua masalah yang teridentifikasi yaitu guru kurang pengoptimalkan penggunaan media pembelajaran.

Permasalahan ini ditindaklanjuti dengan cara menerapkan sebuah model pembinaan kepada guru berupa penerapan Reward dan Punishment yang dilakukan oleh kepala sekolah, kegiatan tersebut diamati kemudian dianalisis dan direfleksi. Hasil revisi kemudian diterapkan kembali pada siklus-siklus. Sesuai dengan jenis penelitian tindakan kelas, penelitian ini menggunakan prosedur kerja dengan siklus spiral dari perencanaan (planning), pelaksanaan (acting), pengamatan (observing), dan refleksi (refleksi) (Fitri \& Haryanti, 2020). Dengan setiap siklusnya peneliti akan melakukan kegiatan yang diawali dengan perencanaan, kemudian melakukan tindakan, observasi terhadap tindakan, dan diakhiri dengan refleksi.

Subyek penelitiannya adalah Guru di SMAN 3 Ponorogo sebanyak 3 guru mata pelajaran Ekonomi di kelas X, XI dan XII. Supervisi klinis sebagai bantuan professional kesejawatan yang diberikan kepada guru yang mengalami masalah dalam pembelajaran agar guru yang bersangkutan dapat mengatasi masalahnya dengan menempuh langkah yang sistematis mencakup tahapan perencanaan, tahapan pengamatan perilaku guru mengajar, serta tahap analisis perilaku dan tindak lanjut. Strategi yang dilakukan oleh kepala sekolah dalam meningkatkan kinerja guru yaitu pemantauan, pemeriksaan, penilaian dan perbaikan. Kinerja guru harus ditingkatkan dan diprioritaskan. Karena seorang guru yang dapat meningkatkan dan mengembangkan kualitas dan potensi peserta didik.

Berdasarkan data dan sumber data yang diperlukan, maka prosedur pengumpulan data menggunakan observasi. Observasi dalam penelitian ini difokuskan pada dengan tahap pelaksanaan tindakan dengan mengisi lembar lembar observasi yang telah disiapkan. Lembar observasi adalah sebuah format isian yang digunakan selama observasi dilakukan. Instrumen Observasi yang digunakan berupa Check List yaitu lembar observasi yang berisikan daftar dari semua aspek yang akan diobservasi sehingga observer tinggal memberi tanda cek $(\sqrt{ })$ tentang aspek yang diobservasi. Check List digunakan untuk mengamati kegiatan guru dalam menggunakan media pembelajaran. Tingkatan 
keberhasilan tindakan didasarkan pada Tabel tingkat penguasaan menurut Purwanto (2008) sebagai berikut:

Tabel 1. Tingkat Keberhasilan Tindakan

\begin{tabular}{|c|c|c|c|}
\hline Tingkat Penguasaan & Nilai Huruf & Bobot & Predikat \\
\hline $86-100 \%$ & A & 4 & Sangat baik \\
$80-85 \%$ & B & 3 & Baik \\
$75-79 \%$ & C & 2 & Cukup \\
$55-74 \%$ & D & 1 & Kurang \\
$\leq 54 \%$ & E & 0 & Sangat Kurang \\
\hline
\end{tabular}

Sementara itu untuk menentukan presentase keberhasilan tindakan didasarkan pada skor yang diperoleh dari data hasil observasi. Untuk menghitung lembar observasi aktivitas guru dan siswa digunakan rumus sebagai berikut:

$$
\begin{aligned}
\mathrm{P} \%= & \frac{X}{\sum X} \times 100 \% \\
\mathrm{X}= & \frac{\sum \text { hasil pengamatan }}{\sum X \text { pengamat }}
\end{aligned}
$$

Dimana $(\mathrm{P} \%)=$ Presentase keberhasilan aktifitas guru dan siswa.

$$
\begin{array}{cl}
\mathrm{X} & =\text { rata-rata } \\
\sum \mathrm{X} & =\text { jumlah rata-rata } \\
\mathrm{P} & =\text { pengamat }
\end{array}
$$

Proses penganalisisan data penelitian ini berpedoman pada langkah-langkah analisis data penelitian kualitatif. Langkah-langkah analisis tersebut terdiri dari tiga alur kegiatan yang terjadi secara bersamaan yaitu: (1) reduksi data, (2) penyajian data, (3) penarikan kesimpulan (Moleong, 2013).

\section{Pembahasan dan Hasil Penelitian}

Penelitian ini merupakan penelitian tindakan berupa supervisi klinis terhadap Guru kelas tinggi pada SMAN 3 Ponorogo, yang dilakukan dengan dua siklus. Adapun hasil penelitian disajikan sebagai berikut:

\section{Deskripsi Kondisi Awal}


Hasil dari refleksi awal kinerja guru kelas tinggi pada SMAN 3 Ponorogo sebelum dilakukan tindakan pada siklus I, didapatkan tingkat kinerja guru seperti disajikan pada Tabel berikut:

Tabel 2. Persentase Kinerja Guru Kelas Tinggi Sebelum Dilakukan Tindakan

\begin{tabular}{|c|l|c|c|c|}
\hline No & \multicolumn{1}{|c|}{ Aspek Kinerja Guru } & $\begin{array}{c}\text { Rerata } \\
\text { Skor }\end{array}$ & $\begin{array}{c}\text { Skor } \\
\text { Ideal }\end{array}$ & Rerata Skor \\
\hline Komponen Rencana Pembelajaran & & & \\
\hline I & Perumusan tujuan pembelajaran & 3,0 & 5 & $60,0 \%$ \\
\hline II & $\begin{array}{l}\text { Pemilihan dan pengorgani-sasian } \\
\text { materi ajar }\end{array}$ & 3,0 & 5 & $60,0 \%$ \\
\hline III & Pemilihan sumber belajar/ media & $\mathbf{2 , 5}$ & $\mathbf{5}$ & $\mathbf{5 0 , 0 \%}$ \\
\hline IV & Metode pembelajaran & 3 & 5 & $50,0 \%$ \\
\hline V & Penilaian hasil belajar & 3 & 5 & $50,0 \%$ \\
\hline & Total & 14,50 & 25 & $58,0 \%$ \\
\hline Komponen Pelaksanaan Pembelajaran & & & \\
\hline I & Pra Pembelajaran & 2 & 4 & $50,0 \%$ \\
\hline II & Membuka Pembelajaran & 2 & 4 & $50,0 \%$ \\
\hline III & Kegiatan Inti Pembelajaran & 2,5 & 4 & $62,5 \%$ \\
\hline & a. Penguasaan Materi & 2,5 & 4 & $62,5 \%$ \\
\hline & b. Pendekatan/Strategi & $\mathbf{2}$ & $\mathbf{4}$ & $\mathbf{5 0 , 0 \%}$ \\
\hline & c. Pemanfaatan Sumber Belajar & 2,5 & 4 & $62,5 \%$ \\
\hline & d. Pengelolaan belajar peserta didik & 2 & 4 & $50,0 \%$ \\
\hline & e. Penilaian proses dan hasil belajar & 3 & 4 & $75,0 \%$ \\
\hline & f. Penggunaan bahasa & 2,5 & 4 & $62,5 \%$ \\
\hline IV & Penutup & 21 & 36 & $58,3 \%$ \\
\hline & Total & & $\mathbf{5 8 , 2 \%}$ \\
\hline & \multicolumn{1}{|c|}{ Keseluruhan } \\
\hline
\end{tabular}

Dari Tabel di atas terlihat bahwa kinerja guru kelas tinggi mencapai ratarata skor 58,2\%, yang meliputi komponen perencanaan pembelajaran sebesar 58,0\% dan komponen pelaksanaan pembelajaran 58,3\%. Kategori persentase kinerja guru tersebut termasuk pada kategori yang Kurang. Persentase komponen perencanaan pembelajaran guru relatif lebih rendah dari pada komponen pelaksanaanya, hal ini menunjukkan bahwa guru belum begitu baik dalam merencanaakan pembelajarannya.

Persentase kinerja guru komponen perencanaan pembelajaran meliputi: (1) perumusan tujuan pembelajaran sebesar $60,0 \%$, (2) pemilihan dan pengorganisasian materi ajar sebesar $60,0 \%$, (3) pemilihan sumber belajar/media pembelajaran sebesar $50,0 \%$, (4) metode pembelajaran sebesar 50,0\%, dan (5) rencana penilaian hasil belajar sebesar 50,0\%, dari data tersebut nampak bahwa guru kurang merencanakan pemilihan 
sumber belajar/media pembelajaran karena persentasenya cukup kecil yang hanya mencapai 50,0\%.

Pada komponen pelaksanaan pembelajaran didapatkan persentase rata-rata skor kinerja pada setiap aspek adalah: (1) Pra pembelajaran sebesar 50,0\%, (2) membuka pelajaran sebesar 50,0\%, (3) kegiatan inti pembelajaran yang meliputi: (a) penguasaan materi sebesar 62,5\%, (b) pendekatan/strategi sebesar 62,5\%, (c) pemanfaatan sumber belajar 50,0\%, (d) pengelolaan belajar peserta didik 62,5\%, (e) penilaian proses dan hasil belajar sebesar 50,0\%, (f) penggunaan bahasa sebesar 75,5\%, dan (4) penutup sebesar $62,5 \%$.

Dari data tersebut yang paling rendah adalah kinerja guru dalam pemanfaatan sumber belajar yang relatif rendah hanya sebesar 50,0\%, dan juga pada bagian penilaian proses dan hasil belajar 50,0\%, hal ini pada umumnya guru pada akhir sesi pembelajaran tidak memberikan refleksi atau membuat rangkuman yang melibatkan peserta didik, serta kurang memberikan arahan tindak lanjut, kegiatan untuk menambah pengayaan materi yang diajarkan kepada peserta didik. Pemanfaatan sumber belajar relatif kurang, mediamedia yang dapat digunakan untuk pembelajaran relatif kurang banyak dimanfaatkan.

Hal-hal tersebut berdampak pada rendahnya hasil belajar peserta didik pada mata pelajaran Ekonomi, dengan nilai rata-rata yang diperoleh adalah seperti pada Tabel berikut:

Tabel 3. Nilai rata-rata Ulangan harian Mata Pelajaran Ekonomi SMAN 3

Ponorogo

\begin{tabular}{|l|c|c|c|c|}
\hline No & Nama Guru & Kelas & Mapel & Nilai Rata-rata \\
\hline 1 & NST & X & Ekonomi & 50,33 \\
\hline 2 & MNT & XI & Ekonomi & 49,85 \\
\hline 3 & KLM & XII & Ekonomi & 45,44 \\
\hline
\end{tabular}

\section{Deskripsi Hasil Siklus I}

\section{a. Persiapan}

Pada kegiatan persiapan yang dilakukan pembuatan rencana pembelajaran yang dikerjakan oleh guru-guru Kelas Tinggi. Tujuan dari kegiatan ini adalah cara melaksanakan pembelajaran yang menerapkan Pembelajaran Aktif Inovatif kreatif dan menyenangkan. Guru diharapkan mengajar yang menerapkan Pembelajaran Aktif Inovatif kreatif dan menyenangkan. 
Selanjutnya dilanjutkan dengan evaluasi mengenahi pelaksanaan pembelajaran, untuk mengevaluasi kekurangan-kekurangan maupun kelebihan pada pelaksanaan pembelajaran tersebut. Kemudian dilanjutkan kegiatan pembuatan persiapan pembelajaran seperti Rencana Pelaksanaan Pembelajaran (RPP), penyiapan alat dan bahan belajar, dan alat evaluasi.

b. Pelaksanaan

Pada tahap ini guru guru kelas tinggi melaksanakan pembelajaran sesuai RPP yang telah dibuat guru kelas secara bersama-sama. Salah satu Guru kelas yang bernama Inisial NST melaksanakan pembelajaran yang diamati secara kolaboratif antara Kepala Sekolah dan MNT. Setelah pembelajaran selesai lalu dilaksanakan review terhadap pembelajaran yang telah dilaksanakan oleh KLM sesuai dengan hasil pengamatan 2 orang abservator. Kemudian pada tanggal yang berbeda dilaksanakan pembelaran di kelas V oleh MNT yang diamati oleh Kepala Sekolah dan NST. Kemudian dilakukan review terhadap pelaksanaan pembelajaran seperti pada kegiatan pembelajaran yang pertama. Kemudian pada tanggal yang berbeda dilaksanakan pembelajaran di kelas IV oleh KLM yang diamati oleh Kepala Sekolah dan NST. Kemudian dilakukan review terhadap pelaksanaan pembelajaran seperti pada kegiatan pembelajaran yang pertama.

c. Pengamatan

Kegiatan pengamatan terhadap pelaksanaan pembelajaran dilakukan secara kolaboratif antara Kepala Sekolah dan guru mata pelajaran. Pada saat NST. melaksanakan pembelajaran maka yang mengamati Kepala Sekolah dan MNT. sedangkan pada saat KLM melaksanakan pembelajaran maka yang mengamati Kepala Sekolah dan NST. Dan pada saat MNT melaksanakan pembelajaran diamati oleh Kepala Sekolah dan NST. juga pada saat NST melaksanakan pembelajaran diamati oleh Kepala Sekolah dan KLM.

d. Refleksi

Hasil dari refleksi awal kinerja guru Kelas Tinggi pada SMAN 3 Ponorogo setelah dilakukan tindakan pada siklus I, didapatkan tingkat kinerja guru seperti disajikan pada tabel berikut.

Tabel 4. Persentase Kinerja Guru Kelas Hasil Tindakan

Siklus I

\begin{tabular}{|l|l|l|l|l|}
\hline Aspek Kinerja Guru & Rerata & Skor & \% Rerata Skor \\
\hline
\end{tabular}




\begin{tabular}{|c|c|c|c|c|}
\hline & & Skor & Ideal & \\
\hline \multicolumn{5}{|c|}{ Komponen Rencana Pembelajaran } \\
\hline I & Perumusan tujuan pembelajaran & 3,5 & 5 & $75,0 \%$ \\
\hline II & $\begin{array}{l}\text { Pemilihan dan pengorgani-sasian } \\
\text { materi ajar }\end{array}$ & 3,5 & 5 & $75,0 \%$ \\
\hline III & $\begin{array}{l}\text { Pemilihan sumber belajar/ media } \\
\text { pembelajaran }\end{array}$ & 3 & 5 & $60,0 \%$ \\
\hline IV & Metode pembelajaran & 3,5 & 5 & $75,0 \%$ \\
\hline \multirow[t]{2}{*}{$\mathrm{V}$} & Penilaian hasil belajar & 3,5 & 5 & $75,0 \%$ \\
\hline & Total & 17 & 25 & $68,0 \%$ \\
\hline \multicolumn{5}{|c|}{ Komponen Pelaksanaan Pembelajaran } \\
\hline I & Pra Pembelajaran & 2,5 & 4 & $62,5 \%$ \\
\hline II & Membuka Pembelajaran & 2,5 & 4 & $62,5 \%$ \\
\hline \multirow[t]{7}{*}{ III } & Kegiatan Inti Pembelajaran & & & \\
\hline & a. Penguasaan Materi & 3 & 4 & $75,0 \%$ \\
\hline & b. Pendekatan/Strategi & 3 & 4 & $75,0 \%$ \\
\hline & c. Pemanfaatan Sumber Belajar & 3 & 4 & $75,0 \%$ \\
\hline & d. Pengelolaan belajar peserta didik & 3 & 4 & $75,0 \%$ \\
\hline & e. Penilaian proses dan hasil belajar & 3 & 4 & $75,0 \%$ \\
\hline & f. Penggunaan bahasa & 3 & 4 & $75,0 \%$ \\
\hline \multirow[t]{2}{*}{ IV } & Penutup & 3 & 4 & $75,0 \%$ \\
\hline & Total & 26 & 36 & $72,2 \%$ \\
\hline \multicolumn{4}{|c|}{ Keseluruhan } & $70,1 \%$ \\
\hline
\end{tabular}

Dari Tabel di atas terlihat bahwa kinerja guru Kelas SMAN 3 Ponorogo setelah dilakukan supervisi klinis didapatkan persentase skor skor kinerja terjadi peningkatan dari $58,2 \%$ menjadi $70,1 \%$. Kategori persentase kinerja guru tersebut termasuk pada kategori yang kurang. Persentase semua aspek terjadi peningkatan yang dengan hasil persentasi sebagai berikut: komponen perencanaan pembelajaran sebesar 58,0\% menjadi $68,0 \%$ dan komponen pelaksanaan pembelajaran dari 58,3\% menjadi 72,2\%. Nampak bahwa pada komponen perencanaan pembelajaran guru telah meningkat, yang berdampak pada pelaksanaannya jauh lebih meningkat lagi, manum demikian hal ini masih menunjukkan bahwa persiapan guru sebelum mengajar masih lebih rendah dibandingkan dengan pelaksanaannya. 
Persentase kinerja guru pada setiap komponen perencanaan pembelajaran hasil siklus I adalah: (1) perumusan tujuan pembelajaran sebesar 75,0\%, (2) pemilihan dan pengorganisasian materi ajar sebesar 75,0\%, (3) pemilihan sumber belajar/media pembelajaran sebesar $60,0 \%$, (4) metode pembelajaran sebesar 75,0\%, dan (5) rencana penilaian hasil belajar sebesar $75,0 \%$, dari data tersebut nampak bahwa guru dalam merencanakan pemilihan sumber belajar/media pembelajaran karena persentasenya masih paling kecil yang baru mencapai 60,0\%.

Pada komponen pelaksanaan pembelajaran didapatkan persentase rata-rata skor kinerja hasil siklus I pada setiap aspek adalah: (1) Pra pembelajaran sebesar 62,5\%, (2) membuka pelajaran sebesar $62,5 \%$, (3) kegiatan inti pembelajaran yang meliputi: (a) penguasaan materi sebesar 75,0\%, (b) pendekatan/strategi sebesar 75,0\%, (c) pemanfaatan sumber belajar 75,0\%, (d) pengelolaan belajar peserta didik 75,0\%, (e) penilaian proses dan hasil belajar sebesar 75,0\%, (f) penggunaan bahasa sebesar 75,0\%, dan (4) penutup sebesar 75,0\% .

Dari data tersebut yang paling rendah adalah kinerja guru dalam pemanfaatan sumber belajar telah terjadi peningkatan yang cukup baik mencapai $75,0 \%$, hal ini menunjukkan bahwa guru telah dapat memanfaatkan sumber belajar sehingga peserta didik dapat lebih optimal dalam belajarnya. Aspek yang relatif paling rendah hasil siklus I pada pelaksanaan pembelajaran adalah pengelolaan belajar peserta didik yaitu pembelajaranyang memicu dan memelihara keterlibatan peserta didik menumbuhkan partisipasi aktif peserta didik melalui interaksi guru, peserta didik, dan sumber belajar merespon positif partisipasi si peserta didik, menunjukkan sikap terbuka terhadap respon peserta didik, menunjukkan hubungan antar priobadi yang kondusif, dan menumbuhkan kecerriaan dan antusiasme peserta didik dalam belajar.

Peningkatan kinerja guru tersebut berdampak pula pada peningkatan hasil belajar peserta didik pada mata pelajaran Ekonomi, dengan nilai rata-rata yang diperoleh relatif lebih tinggi dibandingkan dengan nilai sebelummnya yang dapat dilihat seperti pada tabel berikut.

\section{Tabel 5. Nilai Rata-Rata Ulangan Harian Mata Pelajaran Ekonomi Di SMAN 3}

\section{Ponorogo}

\section{Siklus I}

\begin{tabular}{|c|c|c|c|}
\hline No & Nama Guru & Kelas & $\begin{array}{c}\text { Rata-rata } \\
\text { Nilai Ekonomi }\end{array}$ \\
\hline 1 & NST & $\mathrm{X}$ & 54,35 \\
\hline
\end{tabular}




\begin{tabular}{|l|l|l|l|}
\hline 2 & MNT & XI & 53,15 \\
\hline 3 & KLM & XII & 49,85 \\
\hline
\end{tabular}

Dari Tabel tersebut terlihat bahwa terjadi peningkatan rata-rata nilai Mata Pelajaran Ekonomi pada setiap kelas setelah dilakukan supervisi klinis terhadap guru. Pada SMAN 3 Ponorogo meningkat sebesar 35,5\%.

\section{Hasil Tindakan Siklus II}

a. Persiapan

Pada kegiatan persiapan pada siklus II yaitu kegiatan pembuatan persiapan pembelajaran seperti Rencana Pelaksanaan Pembelajaran (RPP), penyiapan alat dan bahan belajar, dan alat evaluasi. Dengan adanya penyempurnan-penyempurnan dari kekurangan yang mesih ada pada kegiatan Siklus I. sehingga persiapan pada siklus II ini dirasa lebih mantab dan sempurna jika dibandingkan persiapan pada siklus I

b. Pelaksanaan

Pada tahap ini guru Kelas Tinggi melaksanakan pembelajaran sesuai RPP yang telah dibuat secara bersama-sama. Salah satu Guru Kelas XII yang bernama NST melaksanakan pembelajaran Ekonomi di kelas XII yang diamati secara kolaboratif antara Kepala Sekolah dan MNT. Setelah pembelajaran selesai lalu dilaksanakan review terhadap pembelajaran yang telah dilaksanakan oleh NST sesuai dengan hasil pengamatan 2 orang abservator. Kemudian pada tanggal yang berbeda dilaksanakan pembelaran di kelas XI oleh MNT yang diamati oleh Kepala Sekolah dan NST. Kemudian dilakukan review terhadap pelaksanaan pembelajaran seperti pada kegiatan pembelajaran yang pertama. Kemudian pada tanggal yang berbeda dilaksanakan pembelaran di kelas X oleh KLM yang diamati oleh Kepala Sekolah dan NST. Kemudian dilakukan review terhadap pelaksanaan pembelajaran seperti pada kegiatan pembelajaran yang pertama. Kemudian dilakukan review terhadap pelaksanaan pembelajaran seperti pada kegiatan pembelajaran yang kedua.

c. Pengamatan

Pada tahap ini guru Kelas Tinggi melaksanakan pembelajaran sesuai RPP yang telah dibuat guru Ekonomi secara bersama-sama. Salah satu Guru Kelas yang bernama NST melaksanakan pembelajaran Ekonomi di kelas XII yang diamati secara kolaboratif antara Kepala Sekolah dan MNT Setelah pembelajaran selesai lalu dilaksanakan review terhadap pembelajaran yang telah dilaksanakan oleh NST sesuai 
dengan hasil pengamatan 2 orang abservator. Kemudian pada tanggal yang berbeda dilaksanakan pembelaran di kelas XI oleh MNT yang diamati oleh Kepala Sekolah dan NST. Kemudian dilakukan review terhadap pelaksanaan pembelajaran seperti pada kegiatan pembelajaran yang pertama. Kemudian pada tanggal yang berbeda dilaksanakan pembelaran di kelas X oleh KLM yang diamati oleh Kepala Sekolah dan NST. Kemudian dilakukan review terhadap pelaksanaan pembelajaran seperti pada kegiatan pembelajaran yang pertama. Kemudian dilakukan review terhadap pelaksanaan pembelajaran seperti pada kegiatan pembelajaran yang kedua.

d. Refleksi

Hasil dari refleksi kinerja guru Kelas Tinggi pada SMAN 3 Ponorogo setelah dilakukan tindakan pada siklus II, didapatkan tingkat kinerja guru seperti disajikan pada tabel berikut. Hasil refleksi dari hasil tindakan pada Siklus I selanjutnya dijadikan sebagai dasar untuk melakukan supervisi klinis terhadap guru Kelas Tinggi SMAN 3 Ponorogo pada tahap selanjutnya, supervisi yang dilakukan yaitu membantu guru mengidentifikasi kekurangan-kekurangan mulai dari perencanaan sampai dengan pelaksanaan pembelajaran, yang mereka hadapi. Selanjutnya diberikan arahan-arahan yang lebih operasional dan mudah dilaksanakan oleh guru dengan upaya lebih memberikan kemudahan belajar bagi para peserta didik.

Tindakan supervisi inividual dilakukan, yang berdasarkan hasil pengamatan permasalahan yang dihadapi oleh setiap guru relatif sama, yaitu guru masih lemah untuk berinovasi dalam menyiapkan sumber dan media pembelajaran, umumnya guru terjebak pada rutinitas pembelajaran yang mereka lakukan. Selanjutnya setiap guru disarankan untuk meningkatkan inovasi dalam menggunakan media-media pembelajaran dan sumber-sumber belajar sehingga dalam menyampaikan materi pembelajarannya lebih mudah diterima dan disepar para peserta didik. Hasil tes kinerja setelah dilakukan tindakan pada siklus II didapatkan seperti pada tabel 6.

Tabel 6. Persentase Kinerja Guru Kelas Tinggi hasil Tindakan

Siklus II

\begin{tabular}{|l|l|c|c|c|}
\hline \multicolumn{2}{|c|}{ Aspek Kinerja Guru } & $\begin{array}{c}\text { Rerata } \\
\text { Skor }\end{array}$ & Skor Ideal & $\%$ Rerata Skor \\
\hline \multicolumn{2}{|l|}{ Komponen Rencana Pembelajaran } & & & \\
\hline I & Perumusan tujuan pembelajaran & 4,5 & 5 & $90,0 \%$ \\
\hline II & $\begin{array}{l}\text { Pemilihan dan pengorgani-sasian } \\
\text { materi ajar }\end{array}$ & 4,5 & 5 & $90,0 \%$ \\
\hline
\end{tabular}




\begin{tabular}{|c|c|c|c|c|}
\hline III & $\begin{array}{l}\text { Pemilihan sumber belajar/ media } \\
\text { pembelajaran }\end{array}$ & 4 & 5 & $80,0 \%$ \\
\hline IV & Metode pembelajaran & 4 & 5 & $80,0 \%$ \\
\hline \multirow[t]{2}{*}{$\mathrm{V}$} & Penilaian hasil belajar & 4 & 5 & $80,0 \%$ \\
\hline & Total & 21 & 25 & $84,0 \%$ \\
\hline \multicolumn{5}{|c|}{ Komponen Pelaksanaan Pembelajaran } \\
\hline I & Pra Pembelajaran & 4 & 4 & $100,0 \%$ \\
\hline II & Membuka Pembelajaran & 4 & 4 & $100,0 \%$ \\
\hline \multirow[t]{7}{*}{ IIII } & Kegiatan Inti Pembelajaran & & & \\
\hline & a. Penguasaan Materi & 3 & 4 & $75,0 \%$ \\
\hline & b. Pendekatan/Strategi & 3 & 4 & $75,0 \%$ \\
\hline & c. Pemanfaatan Sumber Belajar & 3 & 4 & $75,0 \%$ \\
\hline & d. Pengelolaan belajar peserta didik & 3 & 4 & $75,0 \%$ \\
\hline & e. Penilaian proses dan hasil belajar & 3 & 4 & $75,0 \%$ \\
\hline & f. Penggunaan bahasa & 3 & 4 & $75,0 \%$ \\
\hline \multirow[t]{2}{*}{ IV } & Penutup & 4 & 4 & $100,0 \%$ \\
\hline & Total & 30 & 36 & $83,3 \%$ \\
\hline \multicolumn{4}{|c|}{ Keseluruhan } & $83,7 \%$ \\
\hline
\end{tabular}

Dari Tabel 6 terlihat bahwa kinerja guru Kelas Tinggi setelah dilakukan supervisi klinis didapatkan persentase skor skor kinerja terjadi peningkatan dari 70,1\% menjadi $83,7 \%$. Kategori persentase kinerja guru tersebut termasuk pada kategori yang baik. Persentase semua aspek terjadi peningkatan yang dengan hasil persentasi sebagai berikut: komponen perencanaan pembelajaran sebesar 68,0\% menjadi 84,0\% dan komponen pelaksanaan pembelajaran dari 70,1 menjadi 83,3\%. Nampak bahwa pada komponen perencanaan pembelajaran guru telah meningkat jauh lebih tinggi, yang berdampak pada pelaksanaannya lebih meningkat lagi. Persentasi kinerja guru dalam perencanaan pembelajaran relatif sama bahkan lebih tinggi dibandingkan dengan persentase kinerja guru dalam pelaksanaanya

Persentase kinerja guru pada setiap komponen perencanaan pembelajaran hasil siklus II adalah: (1) perumusan tujuan pembelajaran sebesar 90,0\%, (2) pemilihan dan pengorganisasian materi ajar sebesar 90,0\%, (3) pemilihan sumber belajar/media pembelajaran sebesar $80,0 \%$, (4) metode pembelajaran sebesar 80,0\%, dan (5) rencana penilaian hasil belajar sebesar $80,0 \%$, dari data tersebut nampak bahwa guru telah dapat 
merencanakan pemilihan sumber belajar/media pembelajaran dengan persentase kinerja mencapai $80,0 \%$.

Pada komponen pelaksanaan pembelajaran didapatkan persentase rata-rata skor kinerja hasil siklus I pada setiap aspek adalah: (1) Pra pembelajaran sebesar 100,0\%, (2) membuka pelajaran sebesar 100,0\%, (3) kegiatan inti pembelajaran yang meliputi: (a) penguasaan materi sebesar 75,0\%, (b) pendekatan/strategi sebesar 75,0\%, (c) pemanfaatan sumber belajar 75,0\%, (d) pengelolaan belajar peserta didik 75,0\%, (e) penilaian proses dan hasil belajar sebesar 75,0\%, (f) penggunaan bahasa sebesar $75,0 \%$, dan (4) penutup sebesar 100,0\%.

Dari data tersebut yang paling rendah adalah kinerja guru dalam pemanfaatan sumber belajar telah terjadi peningkatan yang sangat baik mencapai $83,7 \%$, hal ini menunjukkan bahwa guru telah dapat memanfaatkan sumber belajar sehingga peserta didik dapat lebih optimal dalam belajarnya.

Peningkatan kinerja guru tersebut berdampak pula pada peningkatan hasil belajar peserta didik pada Mata Pelajaran Ekonomi, dengan nilai rata-rata yang diperoleh relatif lebih tinggi dibandingkan dengan nilai sebelummnya yang dapat dilihat seperti pada Tabel berikut.

Tabel 7. Nilai Rata-rata Mata Pelajaran Ekonomi Hasil Siklus II

\begin{tabular}{|c|c|c|c|c|}
\hline No & Nama Guru & Kelas & Mata Pelajaran & Rata-rata Nilai \\
\hline 1 & NST & X & Ekonomi & 64,35 \\
\hline 2 & MNT & XI & Ekonomi & 63,15 \\
\hline 3 & KLM & XII & Ekonomi & 62,45 \\
\hline
\end{tabular}

Dari Tabel tersebut terlihat bahwa terjadi peningkatan rata-rata nilai Mata Pelajaran Ekonomi pada setiap sekolah setelah dilakukan supervisi klinis terhadap guru pada siklus II. Hasil belajar juga meningkat yaitu Kelas X sebesar 64,35, Kelas XI sebesar 63,15 dan Kelas XII sebesar 62,45.

\section{Pembahasan}

Selanjutnya hasil refleksi akhir dapat dilihat peningkatan yang lebih jelas kinerja guru dari mulai tes awal, siklus I, dan siklus II dapat digambarkan seperti pada Tabel berikut ini.

Tabel 8. Persentase Kinerja Guru Kelas Tinggi dari keadaan Awal, Hasil Siklus I, dan Siklus II 


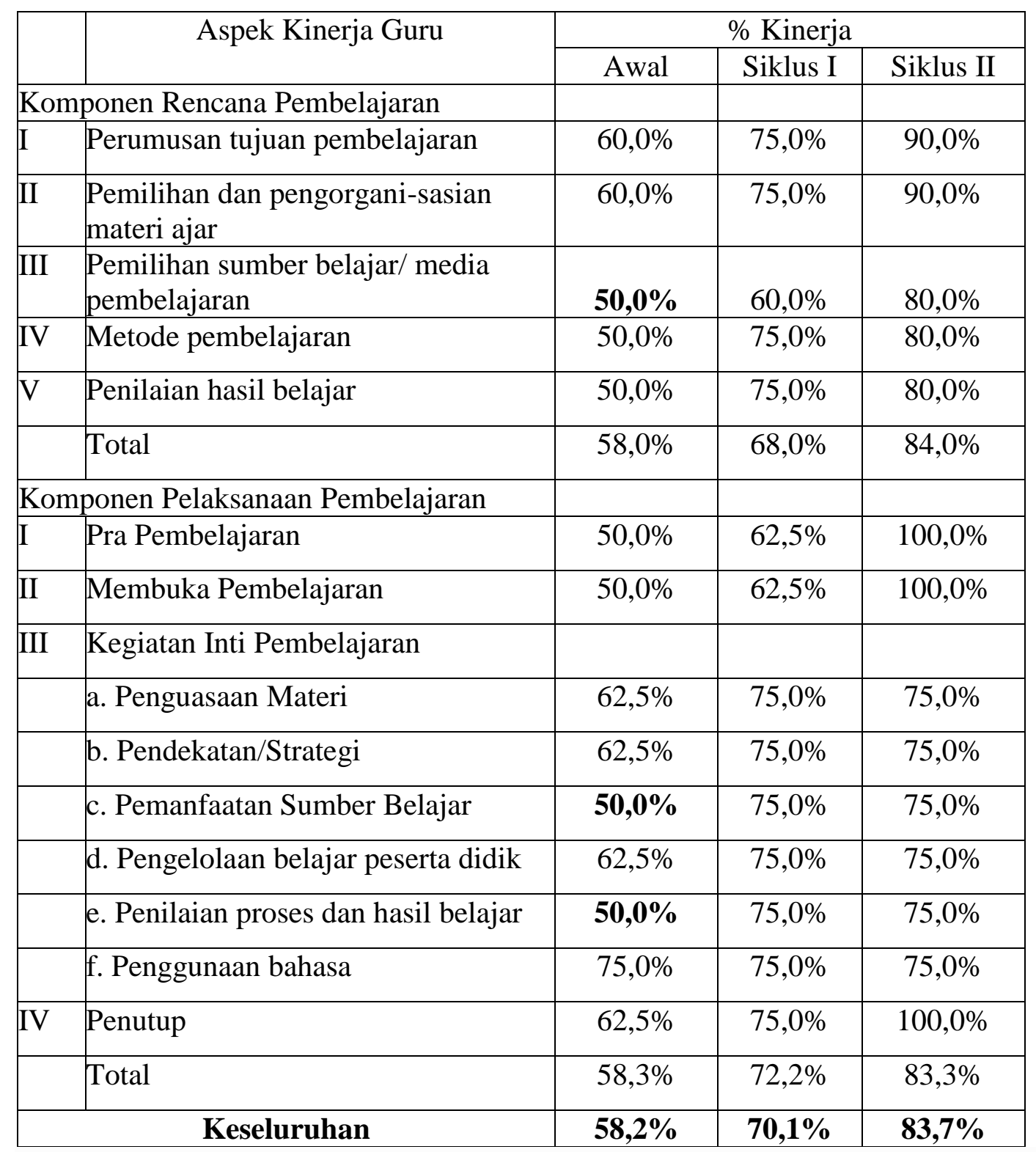

Dari Tabel tersebut nampak bahwa terjadi peningkatan kinerja guru dari awal sebelum tindakan sebesar 58,2\%, setelah tindakan siklus I menjadi $70,1 \%$, dan setelah tindakan siklus II meningkat lagi menjadi $83,7 \%$. Dari data tersebut terlihat bahwa terjadi peningkatan yang cukup tajam dari awal, setelah siklus I, sampai dengan setelah tindakan siklus II.

Selanjutnya perkembangan rata-rata peningkatan nilai hasil belajar peserta didik dapat dilihat seperti pada tabel berikut:

Tabel 9. Nilai Rata-rata Mata Pelajaran Ekonomi kondisi Awal Hasil Siklus I, dan II

\begin{tabular}{|l|l|l|l|}
\hline No & Nama Guru & Rata-rata Nilai \\
\hline
\end{tabular}


Upaya Kepala Sekolah Dalam Meningkatkan Kinerja Guru Ekonomi Melalui Supervisi Klinis di Sekolah Menengah Atas Negeri 3 Ponorogo

\begin{tabular}{|c|c|c|c|c|c|}
\hline & & Kelas & Awal & Siklus I & Siklus II \\
\hline 1 & NST & X & 52,33 & 54,35 & 64,35 \\
\hline 2 & MNT & XI & 49,85 & 53,15 & 63,15 \\
\hline 3 & KLM & XII & 45,44 & 49,85 & 62,45 \\
\hline
\end{tabular}

Selanjutnya untuk mendapatkan gambaran yang lebih jelas peningkatan nilai hasil belajar Ekonomi adalah seperti pada gambar berikut.

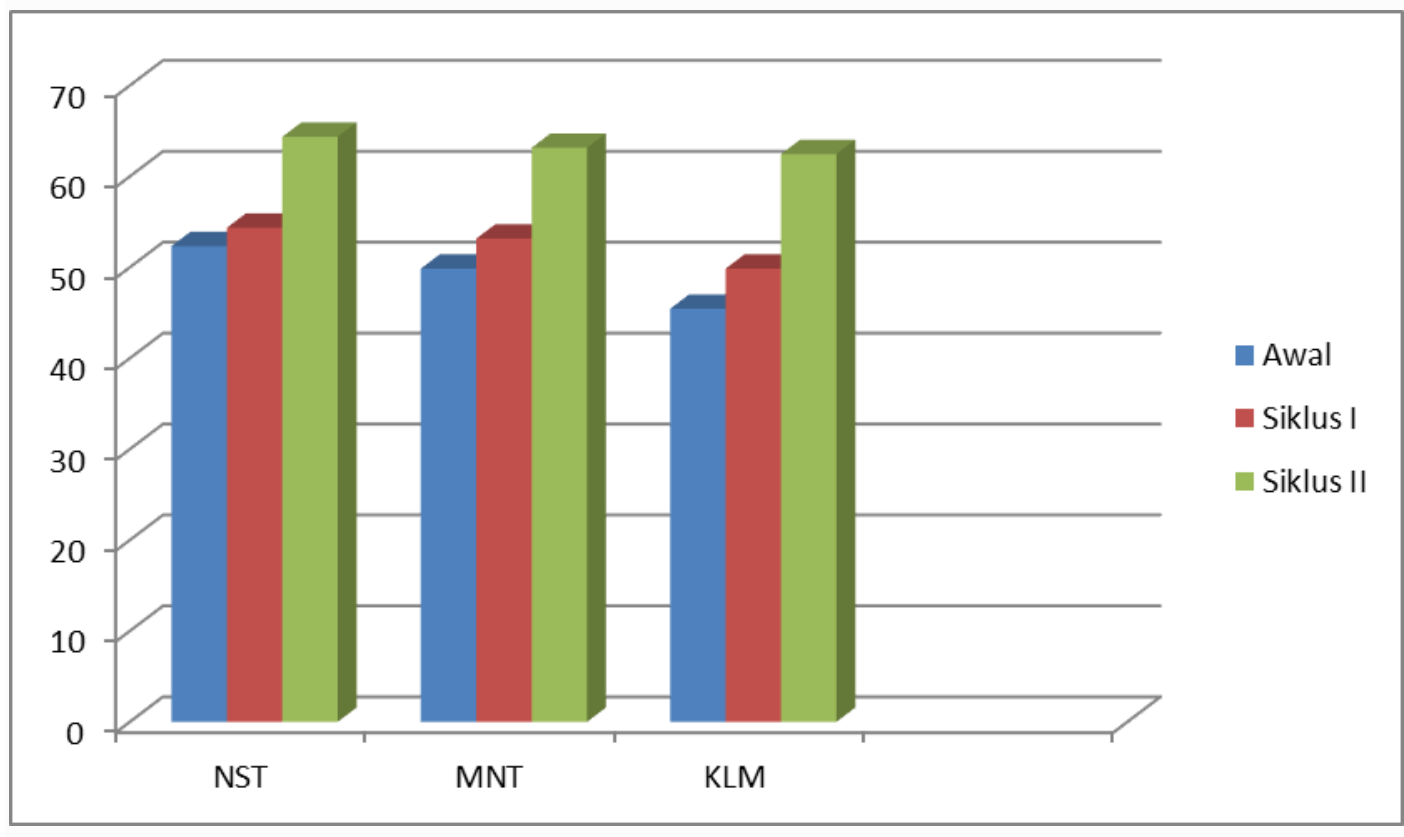

Gambar 1. nilai hasil belajar Ekonomi

Dari Gambar tersebut terlihat bahwa terjadi peningkatan yang tajam dari kondisi awal sampai hasil belajar setelah tindakan pada siklus I, dan terjadi peningkatan pula setelah tindakan siklus II, meskipun peningkatannya tidakterlalu tajam.

Hasil penelitian tindakan supervisi klinis terhadap guru kelas tinggi terbukti memberikan peningkatan kinerja guru yang selanjutnya berdampak pada peningkatan hasil belajar peserta didik. Hal ini dapat dipahami karena jika guru meningkat kinerjanya maka jelas akan terjadi pembelajaran yang efektif dengan kualitas belajar yang optimal, sehingga peserta didik memiliki daya serap terhadap peajarannya yang tinggi pula dan pada akhirnya hasil belajar Mata Pelajaran Ekonomi peserta didik menjadi lebih optimal. Perencanaan guru yang matang dalam mempersiapkan proses belajar mengajar merupakan salah satu kunci keberhasilan peningkatan kualitas pembelajaran.

Supervisi klinis yang diterapkan akan membantu guru dalam menyelesaikan masalah-masalah yang dihadapinya dalam proses pembelajaran sehingga dapat meningkatkan proses dan hasil pembelajaran yang berkualitas (Ansori et al., 2016; 
Humairoh et al., 2016). Supervisi klinis merupakan jawaban untuk mengatasi permasalahan guru dalam pembelajaran (Yulia Jayanti et al., 2016).

Sedangkan, Menurut Archeson \& Gall dalam (Yulia Jayanti et al., 2016) tujuan supervisi klinis adalah meningkatkan pengajaran guru di kelas lebih spesifik lagi, yakni (1) menyediakan umpan balik yang objektif terhadap guru, mengenai pengejaran yang dilaksanakannya, (2) mendiagnosis dan membantu memecahkan masalah-masalah pengajaran, (3) membantu guru mengembangkan keterampilannya menggunakan strategi pengajaran, (4) mengevaluasi guru untuk kepentingan promosi jabatan dan keputusan lainnya, dan (5) membantu guru mengembangkan satu sikap positif terhadap pengembangan profesional yang berkesinambungan. Hasil penelitian ini diperkuat dari penelitian yang dilakuan oleh (Ansori et al., 2016) yang berjudul Pelaksanaan Supervisi Klinis Dalam Meningkatkan Kinerja Guru Sekolah Dasar. Tujuan penelitian ini menggambarkan pelaksanaan supervisi klinis dalam proses pembelajaran di sekolah dasar. Hasil penelitian ini menunjukkan bahwa pelakasanaan supervisi klinis dapat meningkatan kinerja guru dalam proses pembelajaran di sekolah dasar. Selanjutnya, penelitian yang dilakuan oleh (Anuli, 2018) yang berjudul Penerapan Supervisi Klinis Oleh Pengawas Dalam Meningkatkan Keterampilan Mengajar Guru. Dalam penelitiannya dinyatakan bahwa penerapan supervisi klinis oleh pengawas sangat efektif untuk meningkatkan keterampilan guru dalam mengajar.

\section{Kesimpulan}

Berdasarkan hasil penelitian tindakan sekolah di atas dapat disimpulkan bahwa: upaya kepala sekolah melalui supervisi klinis dilakukan pada guru, dapat meningkatkan kinerja guru dibuktikan daripada peningkatan kinerja guru dari awal sebelum tindakan sebesar 58,2\%, setelah tindakan siklus I menjadi 70,1\%, dan setelah tindakan siklus II meningkat lagi menjadi $83,7 \%$. Hasil penelitian tindakan supervisi klinis terhadap guru kelas tinggi terbukti memberikan peningkatan kinerja guru yang selanjutnya berdampak pada peningkatan hasil belajar peserta didik. Hal ini dapat dipahami karena jika guru meningkat kinerjanya maka jelas akan terjadi pembelajaran yang efektif dengan kualitas belajar yang optimal, sehingga peserta didik memiliki daya serap terhadap leajarannya yang tinggi pula dan pada akhirnya hasil belajar Mata Pelajaran Ekonomi peserta didik menjadi lebih optimal. Perencanaan guru yang matang dalam 
Upaya Kepala Sekolah Dalam Meningkatkan Kinerja Guru Ekonomi Melalui Supervisi Klinis di Sekolah Menengah Atas Negeri 3 Ponorogo

mempersiapkan proses belajar mengajar merupakan salah satu kunci keberhasilan peningkatan kualitas pembelajaran.

\section{Daftar Pustaka}

Ansori, Aan, dkk. 2016. Pelaksanaan Supervisi Klinis Dalam Meningkatkan Kinerja Guru Sekolah Dasar. Jurnal Pendidikan: Teori, Penelitian, dan Pengembangan Volume: 1 Nomor: 12 2016, 2321-2326. DOI 10.17977/jp.v1i12.8285

Anuli, Yahya. 2018. Penerapan Supervisi Klinis Oleh Pengawas Dalam Meningkatkan Keterampilan Mengajar Guru. Jurnal Manajemen Pendidikan Islam. Vol. 6 No. 1. https://www.journal.iaingorontalo.ac.id/index.php/tjmpi/article/view/504

Arikunto, Suharsimi. 2004. Dasar-Dasar Supervisi. Jakarta: Rineka Cipta

Fitri, A. Z., \& Haryanti, N. 2020. Metodologi Penelitian Pendidikan. Malang: Madani Media

Humairoh, F., Supriyanto, A., \& Burhanuddin, B. 2016. Implementasi Supervisi Klinis Dalam Meningkatkan Kualitas Pembelajaran Guru Di Sekolah Dasar. Jurnal Pendidikan: Teori,Penelitian Dan Pengembangan. Vol. 12 No.1. https://doi.org/http://dx.doi.org/10.17977/jp.v1i12.8227

Lestari, Iis Dewi. 2019. Implementasi Supervisi Klinis Untuk Meningkatkan Kinerja Guru SMP Ganesa Satria Depok. Faktor Jurnal Ilmiah Kependidikan. Vol. 6 No. 2

Maunah, Binti. 2009. Supervisi Pendidikan Islam (Teori dan Praktik). Yogyakarta: Teras

Moleong, L. J. 2013. Metode Penelitian Kualitatif. Bandung: Remaja Rosdakarya

M. Chotibuddin. 2017. Upaya Kepala Sekolah Dalam Meningkatkan Kretifitas Guru Di Madrasah Ibtidaiyah Muhammadiyah 15 Banjarwati Paciran Lamongan. Jurnal Annaba: Vol. 3No. 1. 2017

Purwanto, M Ngalim. 2007. Administrasi dan Supervisi Pendidikan. Bandung: PT Remaja Rosdakarya

Purwanto, N. 2008. Prinsip-prinsip dan Teknik Evaluasi Pengajaran. Bandung: PT Remaja Rosdakarya

Sahertian, Piet A. 2000. Konsep Dasar dan Teknik Supervisi Pendidikan Dalam Rangka Pengembangan Sumber Daya Manusia. Jakarta: Rineka Cipta

Subhan Adi Santoso, Maulidyah Amalina Rizqi 2020. Kinerja Pengawas Sekolah, Kepala Sekolah, dan Guru pada Pendidikan. Yogyakarta: Deepublish 
Sasmito Pribadi

Subhan Adi Santoso, 2017. Pengaruh Kompetensi Pedagogik Guru Terhadap Prestasi Belajar Siswa Kelas XI Mata Pelajaran PAI Di SMKN 13 Malang. Jurnal Tamaddun: Vol. 18 No. 2. 2017

Subhan Adi Santoso, 2021. Peran Kepala Sekolah Dalam Meningkatkan Mutu Pendidikan Agama Islam Di Madrasah Aliyah Muhammadiyah 02 Paciran Lamongan. Jurnal Annaba: Vol. 7 No. 2. 2017

Soetopo, Hendiyat dan Wasty Soemanto, 1988. Kepemimpinan dan Supervisi Pendidikan, Jakarta: Bina Aksara

Soetopo, Hendyat. 2006. Supervisi Klinis, Bahan Pelatihan Manajemen Pendidikan Bagi Kepala Sekolah pada SUT (Sekolah Unggulan Terpadu Kabupaten Lumajang, tidak diterbitkan, Kerjasama Pemerintah Daerah Lumajang dengan Universitas Negeri Malang

Yulia Jayanti, T., Achmad, S., \& Burhanuddin. (2016). Implementasi Supervisi Klinis Dalam Meningkatkan Profesionalisme Guru. Jurnal Pendidikan: Teori, Penelitian, Dan Pengembangan, Vol. 11 No.1(). http://dx.doi.org/10.17977/jp.v1i11.8127 